\title{
PENGARUH STRATEGI PEMBELAJARAN DAN BERPIKIR KRITIS TERHADAP HASIL BELAJAR IPA SISWA SEKOLAH DASAR
}

\author{
Mayasari \\ Sekolah Alam Student Scout \\ email: mayasariyazid@gmail.com
}

\begin{abstract}
This study aims to determine the effect of CTL learning strategies and critical thinking skills on the learning outcomes of material science disorders in human circulatory organs. The study was conducted at SDI Amalina Pondok Aren in the 2018/2019 academic year. The type of research used is quantitative quasi experimental research. The sample consisted of 58 class $V$ students using cluster random sampling. Data obtained in the form of learning outcomes data and critical thinking skills, with instruments in the form of tests. The data obtained were analyzed using two-track Variance (ANAVA) analysis with design factorial by level $2 \times 2$. The results of this study indicate that: (1) student learning outcomes given CTL learning strategies are higher than students given PBL learning strategies, with Fcount $=37.775>$ Ftable $=4.20$ (2) there is an interaction effect between learning strategies and critical thinking skills, with Fcount $=114.744>$ Ftable $=4.20$ (3) science learning outcomes of students given CTL learning strategies and have high critical thinking skills higher than students who were given PBL learning strategies and had high critical thinking skills, with p-value values (sig: 0,000<0,05) (4) science learning outcomes of students given CTL learning strategies and had lower low critical thinking skills from students given PBL learning strategies and have low critical thinking skills, with p-value (sig: $0.016<0.05$ )
\end{abstract}

Keywords: learning strategies, critical thinking skills, science learning outcomes

\begin{abstract}
Abstrak
Penelitian ini bertujuan untuk mengetahui pengaruh serta interaksi antara strategi pembelajaran dan keterampilan berpikir kritis terhadap hasil belajar IPA, dengan materi gangguan pada organ peredaran darah manusia. Penelitian dilakukan di SDI Amalina Pondok Aren pada tahun pelajaran 2018/2019. Jenis penelitian yang digunakan adalah penelitian kuantitatif quasi experimental. Sampel terdiri dari 58 siswa kelas $\mathrm{V}$ dengan menggunakan cluster random sampling. Kelas eksperimen mendapat perlakuan strategi pembelajaran Contextual Teaching and Learning (CTL) dan kelas kontrol Problem based Learning (PBL). Data yang diperoleh berupa data hasil belajar dan keterampilan berpikir kritis, dengan instrumen berupa tes. Data yang diperoleh dianalisis menggunakan Analisis Varians (ANAVA) dua jalur dengan design factorial by level $2 \times 2$. Hasil penelitian ini menunjukkan bahwa: (1) hasil belajar siswa yang diberikan strategi pembelajaran CTL lebih tinggi dari siswa yang diberikan strategi pembelajaran PBL, dengan $\mathrm{F}_{\text {hitung }}=37,775>\mathrm{F}_{\text {tabe }} \mathrm{l}=$ 4,20 (2) terdapat pengaruh interaksi antara strategi pembelajaran dan kemampuan berpikir kritis, dengan $\mathrm{F}_{\text {hitung }}=114,744>\mathrm{F}_{\text {tabel }}=4,20$ (3) hasil belajar IPA siswa yang diberikan strategi pembelajaran CTL dan memiliki kemampuan berpikir kritis tinggi lebih tinggi dari siswa yang diberikan strategi pembelajaran PBL dan memiliki kemampuan berpikir kritis tinggi, dengan nilai p-value (sig: $0,000<0,05$ ) (4) hasil belajar IPA siswa yang diberikan strategi pembelajaran CTL dan memiliki kemampuan berpikir kritis rendah lebih rendah dari siswa yang diberikan strategi pembelajaran PBL dan memiliki kemampuan berpikir kritis rendah, dengan nilai p-value (sig: $0,016<0,05)$
\end{abstract}

Kata kunci: strategi pembelajaran, keterampilan berpikir kritis, hasil belajar IPA

\section{PENDAHULUAN}

Implementasi Kurikulum 2013 dilaksanakan secara bertahap, dan pada tahun 2016 telah melewati proses evaluasi serta revisi. Diberlakukannya Kurikulum 2013 adalah usaha pemerintah dalam menyiapkan calon-calon pewaris negeri, yang siap menghadapi tantangan abad 21 . 
Trilling dan Fadel dalam Daryanto (2017:13) menyampaikan bahwa keterampilan yang harus dimiliki pada abad 21 adalah life and career skills, learning and innovation skills, dan information media and technology skills. Oleh karena itu, guru harus mampu membimbing siswa dalam menguasai keterampilanketerampilan yang harus dimilikinya selaras dengan tantangan zaman.

Kurikulum 2013 berbasis kompetensi dan menggunakan pendekatan scientific sebagai proses berpikir, dengan sistem pembelajaran authentik (authentic instruction), implementasi penguatan pendidikan karakter, kecakapan literasi, dan keterampilan berpikir tingkat tinggi (high order thinking skills/HOTS). Salah satu keterampilan berpikir tingkat tinggi adalah keterampilan berpikir kritis (critical thinking skills). Ilmu Pengetahuan Alam (IPA) adalah salah satu mata pelajaran yang mempraktikkan sikap ilmiah. IPA di tingkat sekolah dasar menekankan pentingnya siswa mengalami langsung materi yang dipelajarinya, bukan mendengarkan dari guru saja.

Strategi pembelajaran yang diharapkan untuk diimplementasikan dalam Kurikulum 2013 adalah strategi yang mendorong siswa untuk memiliki kemampuan dalam menganalisis setiap situasi secara logis sehingga siswa memiliki kemampuan berpikir kritis, memecahkan masalah secara kreatif, mampu berkomunikasi dengan baik, senantiasa bekerjasama dan berkolaborasi. Strategi pembelajaran yang digunakan akan menghasilkan kemampuan untuk belajar, namun bukan pada apa yang akan diperoleh melainkan pada proses bagaimana pengetahuan, keterampilan dan sikap diperoleh siswa. Sehingga proses pembelajaran yang diharapkan adalah pembelajaran yang mampu melibatkan siswa secara maksimal diantaranya agar siswa bekerja dalam kelompok, siswa memahami materi pelajaran melalui pengalaman/praktek langsung dan belajar memecahkan masalah.

Namun hal tersebut belum sepenuhnya dilaksanakan. Guru masih cenderung melaksanakan pembelajaran yang bersifat ekspositori atau berpusat pada guru untuk mengejar pencapaian penyampaian materi daripada membuat/mendorong siswa untuk belajar. Oleh karena itu, guru harus mempunyai taktik/cara untuk menjelaskan berbagai hal yang membuat siswa belajar. Salah satunya adalah dengan pemilihan strategi pembelajaran yang tepat. Dan guru harus mampu mengimplementasikan dengan baik serta menyeluruh strategi pembelajaran yang telah dipilihnya

\section{KAJIAN LITERATUR}

Perkembangan dan kemajuan siswa dalam suatu pelajaran/materi dapat dilihat dari hasil belajarnya. Hamalik (2008:155) menjelaskan bahwa hasil belajar sebagai terjadinya perubahan tingkah laku pada diri siswa, yang dapat diamati dan diukur dengan perubahan pengetahuan, sikap dan keterampilan.

Guru memerlukan langkah atau trik untuk mencapai perkembangan dan kemajuan siswa seperti yang diharapkan dalam tujuan pembelajaran. Salah satunya adalah melalui pemilihan strategi pembelajaran yang tepat. Menurut Dick and Carey dalam Sanjaya (2016:126), strategi pembelajaran adalah suatu set materi dan prosedur pembelajaran yang digunakan secara bersama-sama untuk memunculkan hasil belajar siswa. Kegiatan dalam strategi pembelajaran CTL dan PBL secara garis besar adalah memecahkan masalah, sehingga dalam hal ini dibutuhkan keterampilan berpikir kritis siswa. Berlandaskan keterampilan berpikir kritis yang telah siswa miliki, diharapkan pelaksanaan strategi pembelajaran CTL dan 
PBL dapat berimplikasi baik terhadap hasil belajar siswa.

Mulyasa (2009:217-218) menyatakan bahwa CTL adalah konsep yang menekankan pada keterkaitan antara materi pembelajaran dengan kehidupan siswa secara nyata, sehingga para siswa mampu menghubungkan serta menerapkan kompetensi hasil belajar dalam kehidupan sehari-harinya. Menurut Johnson (2014:6885), CTL memiliki tiga prinsip ilmiah, yaitu kesalingbergantungan, diferensiasi, dan pengaturan diri. Al Tabany (2015:145-152) mengemukakan bahwa pembelajaran dengan CTL memiliki tujuh komponen utama, yaitu: konstrukstivisme, inkuiri, bertanya, masyarakat belajar, pemodelan, refleksi, penilaian autentik, sehingga dalam proses pembelajaran dengan strategi CTL ini ketujuh komponen tersebut harus terealisasi.

Tan dalam Rusman (2010:229) menyampaikan bahwa PBL merupakan penggunaan berbagai macam kecerdasan yang diperlukan untuk melakukan konfrontasi terhadap tantangan dunia nyata, kemampuan untuk menghadapi segala sesuatu yang baru dan kompleksitas yang ada. Sementara Oguz (2014:122) menyatakan prinsip utama PBL didasarkan pada memaksimalkan pembelajaran melalui investigasi, penjelasan, dan penyelesaian dengan memulai dari masalah nyata dan bermakna.

Arends (2012:410-414) menjelaskan 5 langkah pengkondisian PBL dalam proses pembelajaran, yaitu:

a. Mengorientasi siswa pada masalah

b. Mengatur siswa dalam belajar

c. Membantu investigasi mandiri dan kelompok

d. Mengambangkan serta mempresentasikan hasil karya dan pameran

e. Mengevaluasi proses pemecahan masalah
Strategi CTL dan PBL masingmasing memiliki kelebihan dan kekurangannya. Oleh karena dalam perencanaan pembelajaran, guru harus dapat memilih strategi yang tepat sesuai dengan materi pembelajaran dan kompetensi serta tujuan yang ingin dicapai. Kegiatan dalam strategi pembelajaran CTL dan PBL secara garis besar adalah memecahkan masalah, sehingga dalam hal ini dibutuhkan keterampilan berpikir kritis siswa. Berlandaskan keterampilan kritis yang telah siswa miliki, diharapkan pelaksanaan strategi pembelajaran CTL dan PBL dapat berimplikasi baik terhadap hasil belajar siswa.

Penerapan keterampilan berpikir kritis salah satunya dapat dilakukan pada mata pelajaran Ilmu Pengetahuan Alam (IPA). IPA di tingkat sekolah dasar menekankan pentingnya siswa mengalami langsung materi yang dipelajarinya, bukan mendengarkan dari guru saja. Menurut Susanto (2014:167), IPA merupakan usaha manusia dalam memahami alam semesta melalui pengamatan yang tepat pada sasaran, serta menggunakan prosedur, dan dijelaskan dengan penalaran sehingga mendapat suatu kesimpulan. Sehingga apabila siswa dapat menanggapi fakta-fakta dan memecahkan masalah di lingkungannya, menunjukkan bahwa keterampilan berpikir kritis siswa berkembang, khususnya dalam mata pelajaran IPA.

Stobaugh (2013:2) menjelaskan bahwa berpikir kritis adalah berpikir yang reflektif secara mendalam dalam pengambilan keputusan dan pemecahan masalah untuk menganalisis situasi, mengevaluasi argumen, dan menarik kesimpulan yang tepat. Menurut Filsaime (2008:74) proses berpikir 
kritis selalu mengacu pada teori Bloom, di mana para siswa mempraktekkan beberapa tingkatan yang lebih rendah dari kecakapan-kecakapan berpikir kritis sebelum mengarahkan mereka pada tugas-tugas yang lebih sulit dari proses berpikir kritis.

\section{METODE PENELITIAN}

Peneliti menggunakan pendekatan eksperimen, dan menurut Creswell (2015:576) eksperimen adalah menguji suatu ide, atau praktik, atau prosedur untuk menentukan apakah ide itu mempengaruhi hasil atau variable dependen. Pendekatan eksperimen adalah suatu cara untuk mencari hubungan sebab akibat (hubungan kausal) antara dua faktor yang sengaja ditimbulkan oleh peneliti. Penelitian ini dirancang menggunakan quasi experimental design with posttest only control group design.

Tujuan dari penelitian ini adalah untuk mengetahui pengaruh serta interaksi antara strategi pembelajaran dan keterampilan berpikir kritis terhadap hasil belajar IPA, dengan materi gangguan pada organ peredaran darah manusia. Oleh karena itu, maka desain penelitian yang digunakan adalah design factorial $2 \times 2$. Menurut Creswell (2015:159) desain faktorial yaitu suatu variasi antara desain kelompok yang terdiri dari dua atau lebih variabel perlakuan untuk menguji variabel bebas dan efek simultan pada variabel perlakuan pada suatu hasil outcome. Berikut adalah tabel desain yang digunakan dalam penelitian ini:
Tabel 1 Design Factorial 2 x 2

\begin{tabular}{|c|c|c|}
\hline $\begin{array}{l}\begin{array}{r}\text { Strategi } \\
\text { pembelajaran } \\
\text { (A) }\end{array} \\
\text { Berpikir kriti } \\
\text { (B) }\end{array}$ & $\begin{array}{l}\text { Contextual } \\
\text { Teaching } \\
\text { and } \\
\text { Learning } \\
\left(\mathrm{A}_{1}\right)\end{array}$ & $\begin{array}{c}\text { Problem } \\
\text { Based } \\
\text { Learning } \\
\left(\mathrm{A}_{2}\right)\end{array}$ \\
\hline Tinggi $\left(B_{1}\right)$ & $\mathbf{A}_{1} \mathbf{B}_{1}$ & $\mathbf{A}_{2} \mathbf{B}_{1}$ \\
\hline Rendah $\left(B_{2}\right)$ & $\mathbf{A}_{1} \mathbf{B}_{2}$ & $\mathbf{A}_{2} \mathbf{B}_{2}$ \\
\hline
\end{tabular}

Keterangan:

$\mathrm{A}_{1} \mathrm{~B}_{1}$ : Kelompok siswa dengan keterampilan berpikir kritis tinggi yang menerima perlakuan strategi pembelajaran Contextual Teaching and Learning

$A_{1} B_{2}$ : Kelompok siswa dengan keterampilan berpikir kritis rendah yang menerima perlakuan strategi pembelajaran Contextual Teaching and Learning

$A_{2} B_{1}$ : Kelompok siswa dengan keterampilan berpikir kritis tinggi yang menerima perlakuan strategi pembelajaran Problem Based Learning

$\mathrm{A}_{2} \mathrm{~B}_{2}$ : Kelompok siswa dengan keterampilan berpikir kritis rendah yang menerima perlakuan strategi pembelajaran Problem Based Learning

Populasi dalam penelitian ini adalah semua siswa SDI Amalina Pondok Aren tahun ajaran 2018/2019. Sampel terdiri dari 58 siswa kelas V dengan menggunakan cluster random sampling. Kelas eksperimen mendapat perlakuan strategi pembelajaran Contextual Teaching and Learning (CTL) dan kelas kontrol Problem based Learning (PBL). Baik kelas eksperimen maupun kelas kontrol mendapat materi yang sama yaitu gangguan pada organ peredaran darah manusia sebanyak 9 kali pertemuan, masing-masing dengan durasi 35 menit. Data yang diperoleh berupa data hasil belajar dan keterampilan berpikir kritis, dengan instrumen berupa tes. Instrumen tes hasil belajar sebanyak 20 soal pilihan ganda dengan ranah 
kognitif C4-C6 dan 12 soal essai untuk keterampilan berpikir kritis. Data yang diperoleh dianalisis menggunakan Analisis Varians (ANAVA) dua jalur.

\section{HASIL DAN PEMBAHASAN}

Sebelum treatment dilakukan, terlebih dahulu dilakukan uji coba soal untuk menentukan validitas dan reliabilitas dari soal tersebut. Hasilnya valid dan reliable sehingga dilanjutkan dengan kegiatan pembelajaran sesuai dengan strategi yang ditetapkan.

Selanjutnya uji normalitas data menggunakan Liliefors dengan hasil sampel penelitian berasal dari data populasi yang berdistribusi normal. Sedangkan uji homogenitas data dilakukan data dilakukan dengan menggunakan uji levene tes untuk mengetahui apakah sampel berasal dari data populasi homogen.

Berdasarkan rancangan penelitian eksperimen yang dilakukan, berikut ini adalah tabel rekapitulasi skor yang dideskripsikan secara terpisah pada 6 (enam) kelompok siswa:

a. Skor hasil belajar IPA dengan strategi pembelajaran CTL $\left(\mathrm{A}_{1}\right)$

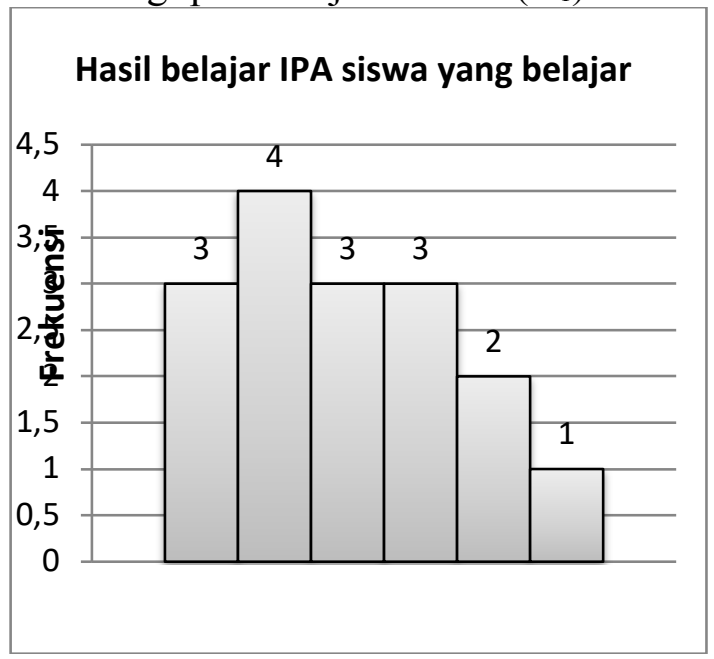

Gambar 1. Histogram skor hasil belajar IPA dengan strategi pembelajaran CTL (A1) b. Skor hasil belajar IPA dengan strategi pembelajaran PBL $\left(\mathrm{A}_{2}\right)$

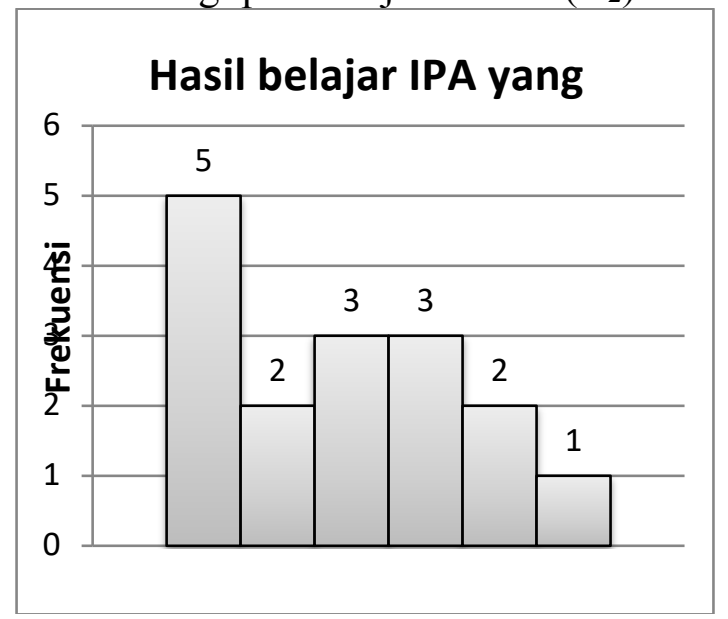

Gambar 2 Histogram skor hasil belajar IPA dengan strategi pembelajaran PBL (A2)

c. Skor hasil belajar IPA siswa yang belajar menggunakan strategi pembelajaran CTL dengan keterampilan berpikir kritis tinggi $\left(\mathrm{A}_{1} \mathrm{~B}_{1}\right)$

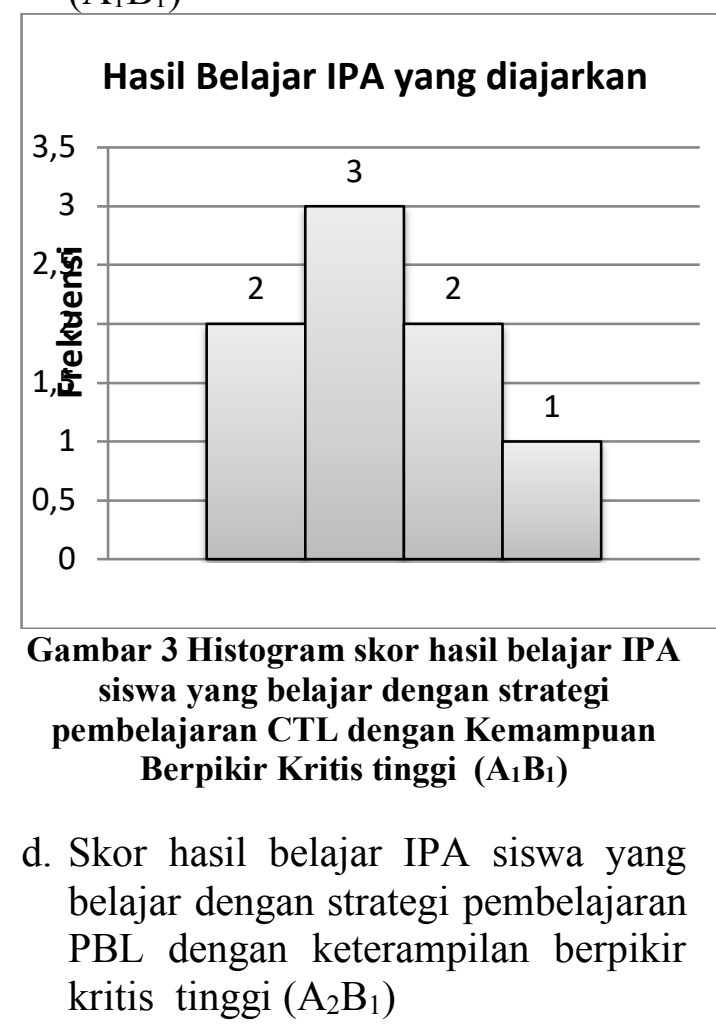




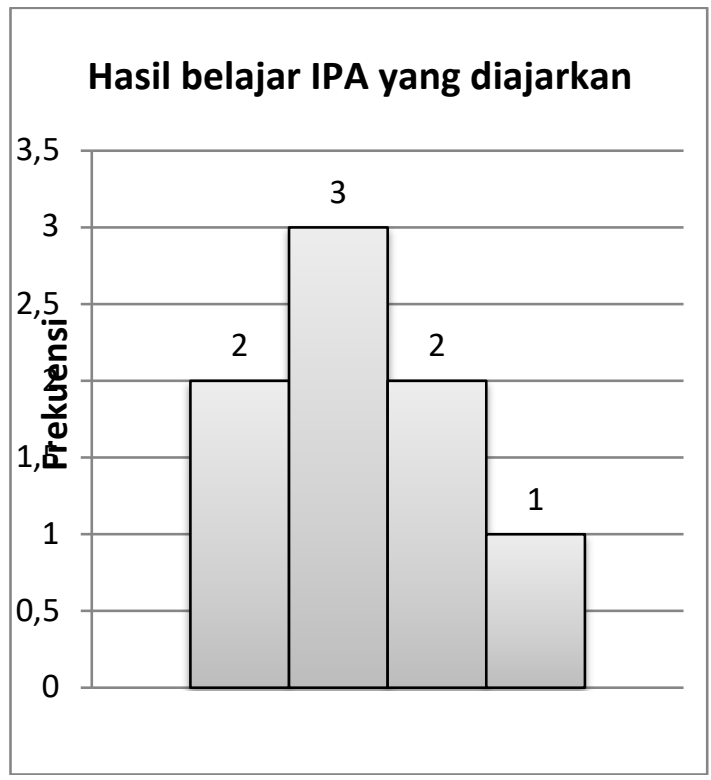

Gambar 4 Histogram Skor hasil belajar IPA siswa yang belajar menggunakan strategi pembelajaran $\mathrm{PBL}$ dengan Kemampuan Berpikir KritisTinggi $\left(\mathrm{A}_{2} \mathbf{B}_{1}\right)$

e. Skor hasil belajar IPA siswa yang belajar menggunakan strategi pembelajaran CTL dengan Kemampuan Berpikir Kritis Rendah $\left(\mathrm{A}_{1} \mathrm{~B}_{2}\right)$

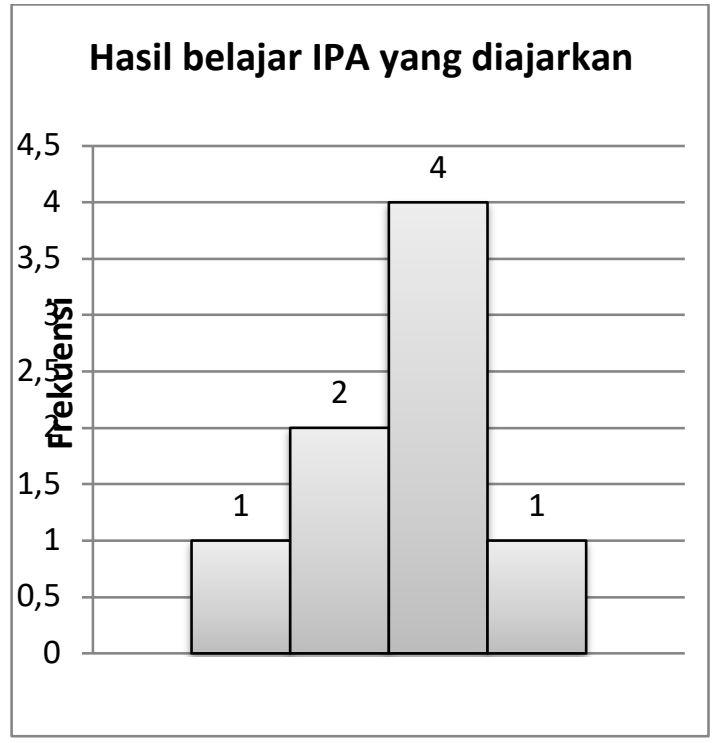

Gambar 5 Histogram Skor hasil belajar IPA siswa yang belajar menggunakan strategi pembelajaran CTL dengan Kemampuan Berpikir KritisRendah $\left(\mathrm{A}_{1} \mathrm{~B}_{2}\right)$ f. Skor Hasil Belajar IPA Siswa yang Belajar dengan Strategi Pembelajaran PBL dengan Kemampuan Berpikir Kritis Rendah $\left(\mathrm{A}_{2} \mathrm{~B}_{2}\right)$

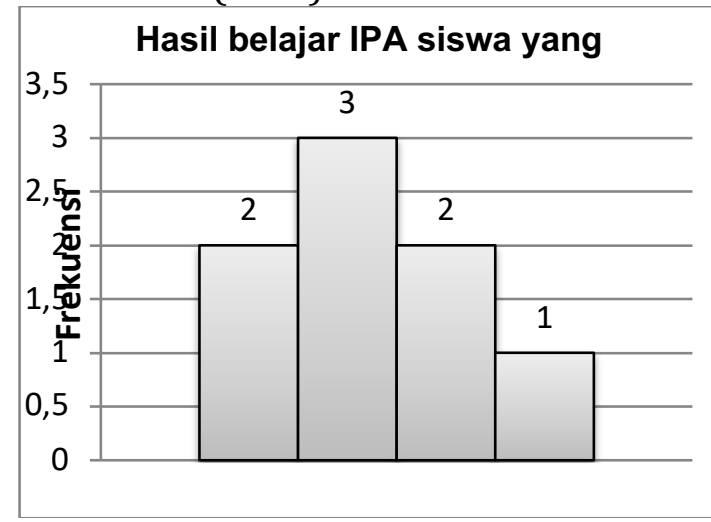

Gambar 6 Histogram skor hasil belajar IPA siswa yang belajar dengan strategi pembelajaran PBL, Kemampuan Berpikir Kritis Rendah $\left(\mathbf{A}_{2} \mathbf{B}_{2}\right)$

Pengujan hipotesis menggunakan teknik analisis varians dua jalur (ANAVA) design treatment by level $2 \times 2$, dengan rangkuman sebagai berikut:

Tabel 1 Rangkuman Hasil

Perhitungan Analisis Varians (ANAVA) Dua Jalur

Tests of Between-Subjects Effects

Dependent Variable: Hasil Belajar IPA

\begin{tabular}{|c|c|c|c|c|c|}
\hline Source & $\begin{array}{l}\text { Type III } \\
\text { Sum of } \\
\text { Squares }\end{array}$ & Df & $\begin{array}{l}\text { Mean } \\
\text { Square }\end{array}$ & $\mathrm{F}$ & Sig. \\
\hline $\begin{array}{l}\text { Corrected } \\
\text { Model }\end{array}$ & $3871.094^{\mathrm{a}}$ & 3 & $\begin{array}{r}1290.36 \\
5\end{array}$ & $\begin{array}{r}50.93 \\
2\end{array}$ & .000 \\
\hline Intercept & $\begin{array}{r}188344.5 \\
31\end{array}$ & 1 & $\begin{array}{r}188344 . \\
531\end{array}$ & $\begin{array}{r}7434 . \\
216\end{array}$ & .000 \\
\hline A & 957.031 & 1 & 957.031 & $\begin{array}{r}37.77 \\
5\end{array}$ & .000 \\
\hline B & 7.031 & 1 & 7.031 & .278 & .602 \\
\hline
\end{tabular}




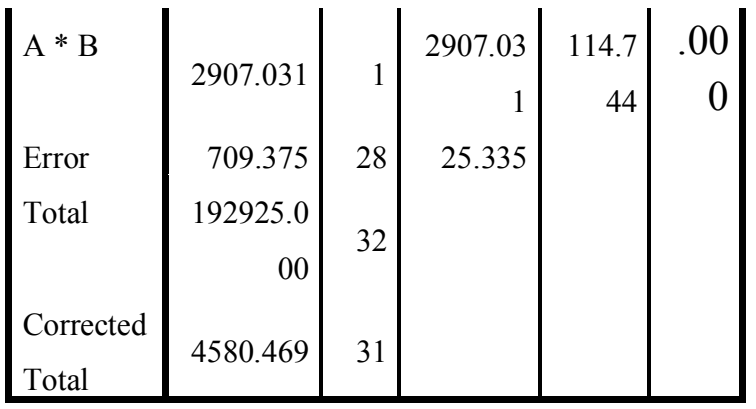

a. $\mathrm{R}$ Squared $=.845$ (Adjusted R Squared

$=.829$ )

Hasil pengujian terhadap hipotesis yang diajukan adalah sebagai berikut:

1. Terdapat perbedaan hasil belajar IPA antara siswa yang belajar dengan strategi pembelajaran CTL dan strategi pembelajaran PBL $\left(\mathrm{A}_{1}\right.$ dan $\mathrm{A}_{2}$ )

Hipotesis statistik dirumuskan sebagai berikut :

$\mathrm{H}_{0}: \mu \mathrm{A}_{1} \leq \mu \mathrm{A}_{2}$

$\mathrm{H}_{1}: \mu \mathrm{A}_{1}>\mu \mathrm{A}_{2}$

Keterangan :

$\mathrm{H}_{0}$ : Tidak terdapat perbedaan hasil belajar IPA antara siswa yang belajar menggunakan strategi pembelajaran CTLdan strategi pembelajaran PBL.

$\mathrm{H}_{1}$ : Terdapat perbedaan hasil belajar IPA antara siswa yang belajar menggunakan strategi pembelajaran CTLdan strategi pembelajaran PBL

$\mu_{\mathrm{A} 1}$ : Rata-rata skor hasil belajar IPA yang belajar menggunakan strategi pembelajaranCTL

$\mu_{\mathrm{A} 2}$ : Rata-rata skor hasil belajar IPA yang belajar dengan strategi pembelajaran PBL

Dalam penelitian telah ditemukan bahwa terdapat perbedaan yang signifikan hasil belajar IPA siswa yang belajar dengan strategi pembelajaran CTL dengan siswa yang belajar menggunakan strategi pembelajaran PBL. Hasil belajar IPA pada siswa yang memilkki strategi pembelajaran CTL lebih tinggi dibandingkan siswa yang menggunakan strategi pembelajaran PBL.

2. Pengaruh interaksi strategi pembelajarandan Kemampuan

Berpikir Kritis terhadap hasil belajar IPA (A X B)

Hipotesis statistik dirumuskan sebagai berikut :

$\mathrm{H}_{0}:$ INT. $\mathrm{A} \times \mathrm{B}=0$

$\mathrm{H}_{1}$ : INT. $\mathrm{A} \times \mathrm{B} \neq 0$

Keterangan :

$\mathrm{H}_{0}$ : Tidak terdapat pengaruh interaksi strategi pembelajarandan Kemampuan Berpikir Kritis terhadap hasil belajar IPA

$\mathrm{H}_{1}$ : Terdapat pengaruh interaksi strategi pembelajaran dan Kemampuan Berpikir Kritisterhadap hasil belajar IPA

Hasil perhitungan ANAVA bahwa $F_{\text {hitung }}$ untuk faktor interaksi yaitu 114,744 lebih besar daripada $\mathrm{F}_{\text {tabel }}$ yaitu 4,20 pada taraf nyata $\alpha=$ 0.05. dengan demikian tolah $\mathrm{H}_{\mathrm{o}}$ dan terima $\mathrm{H}_{1}$ dan dapat disimpulkan Terdapat pengaruh interaksi antara penggunaan strategi pembelajarandan Kemampuan Berpikir Kritisterhadap Skor hasil belajar IPA. Bentuk grafik interaksi antara strategi pembelajaran dan Kemampuan Berpikir Kritis terhadap skor hasil belajar IPA disajikan pada gambar berikut : 


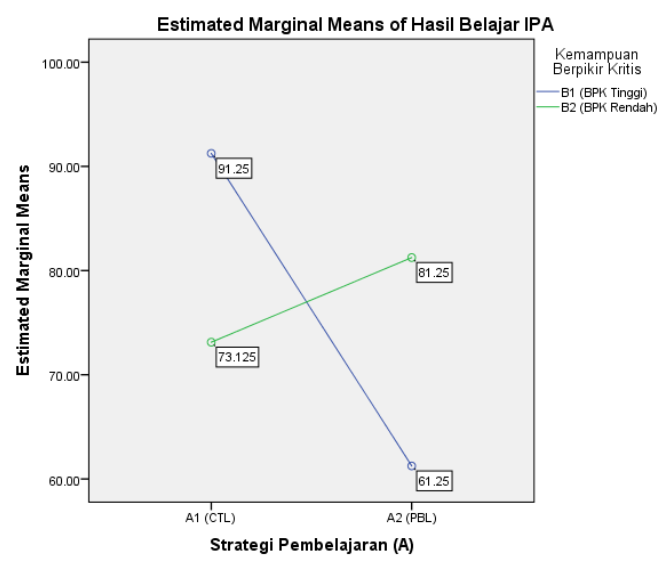

Gambar 7 Grafik interaksi strategi pembelajaran dan keterampilan berpikir kritis terhadap hasil belajar IPA

Berdasarkan hasil perhitungan anava dan terlihat dari gambar grafik Interaksi diatas dapat disimpulkan pada kelompok dengan keterampilan berpikir kritis tinggi lebih tepat jika menggunakan strategi pembelajaran CTL sedangkan pada kelompok dengan keterampilan berpikir kritis rendah lebih tepat menggunakan strategi pembelajaran PBL.

3. Siswa dengan Kemampuan Berpikir KritisTinggimemiliki hasil belajar IPAlebih baik bila dengan strategi pembelajaran CTL

Hipotesis statistik dirumuskan sebagai berikut :

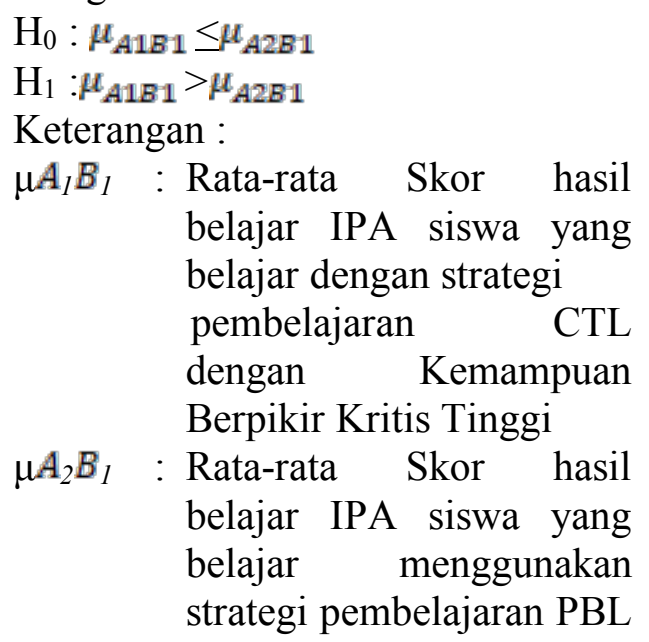

dengan Kemampuan

Berpikir KritisTinggi

Skor hasil belajar IPA siswa yang belajar dengan strategi pembelajaran CTL dengan Keterampilan Berpikir Kritis Tinggi $\left(\mathrm{A}_{1} \mathrm{~B}_{1}\right)$ adalah 91,25 sedangkan skor rata-rata skor hasil belajar IPA yang belajar dengan strategi pembelajaran PBLdengan Keterampilan Berpikir Kritis Tinggi $\left(\mathrm{A}_{2} \mathrm{~B}_{1}\right)$ adalah 61,25 dan Uji Tuckey menunjukkan perbedaan rata-rata skor antara siswa yang belajar dengan strategi pembelajaran CTLdengan Kemampuan Berpikir KritisTinggi $\left(\mathrm{A}_{1} \mathrm{~B}_{1}\right)$ dan siswa yang belajar dengan strategi pembelajaran PBL dengan Kemampuan Berpikir KritisTinggi sebesar 30,00 dan nilai p-value (sig) sebesar 0,000, oleh karena nilai p-value lebih kecil dari nilai alpha $(0,000<0,05)$ dengan demikian dapat disimpulkan $\mathrm{H}_{0}$ ditolak dan $\mathrm{H}_{1}$ diterima yang berarti bahwa untuk Siswa denganKemampuan Berpikir Kritis Tinggi hasil belajar IPA lebih tinggi bila belajar dengan strategi pembelajaran CTL.

4. Siswa dengan keterampilan berpikir kritis rendah, hasil belajar IPA lebih baik pada siswa yang menggunakan strategi pembelajaran $\mathrm{PBL}\left(\mathrm{A}_{1} \mathrm{~B}_{2}\right.$ dan $\mathrm{A}_{2} \mathrm{~B}_{2}$ )

Hipotesis secara statistik dirumuskan sebagai berikut:

$\mathrm{H}_{0}: \mu \mathrm{A}_{1} \mathrm{~B}_{2} \geq \mu \mathrm{A}_{2} \mathrm{~B}_{2}$

$\mathrm{H}_{1}: \mu \mathrm{A}_{1} \mathrm{~B}_{2}<\mu \mathrm{A}_{2} \mathrm{~B}_{2}$

Keterangan :

$\mu A_{1} B_{2}$ : Rata-rata skor hasil belajar IPA siswa yang belajar dengan strategi pembelajaran CTL dengan Kemampuan Berpikir KritisRendah 
$\mu A_{2} B_{2}$ : Rata-rata skor hasil belajar IPA siswa yang belajar menggunakan strategi pembelajaran PBL dengan Kemampuan Berpikir KritisRendah

Skor rata-rata hasil belajar IPAyang belajar dengan strategi pembelajaran CTL dengan Kemampuan Berpikir KritisRendah $\left(\mathrm{A}_{1} \mathrm{~B}_{2}\right)$ adalah 73,13 sedangkan skor rata-rata hasil belajar IPA yang belajar dengan strategi pembelajaran PBLdengan Kemampuan Berpikir $\operatorname{KritisRendah}\left(\mathrm{A}_{2} \mathrm{~B}_{2}\right) \quad$ adalah 81,25dan Uji Tuckey menunjukkan perbedaan rata-rata skor antara siswa yang belajar dengan strategi pembelajaran CTL dengan Kemampuan Berpikir Kritis Rendah $\left(\mathrm{A}_{1} \mathrm{~B}_{2}\right)$ dan siswa yang belajar dengan strategi pembelajaran PBL dengan keterampilan berpikir kritis rendah sebesar 8,125 dan nilai $\mathrm{p}$ value (sig) sebesar 0,016, oleh karena nilai p-value lebih kecil dari nilai alpha $(0,016<0,05)$ dengan demikian dapat disimpulkan $\mathrm{H}_{0}$ ditolak dan $\mathrm{H}_{1}$ diterima yang berarti bahwa untuk Siswa denganKemampuan Berpikir KritisRendahhasil belajar IPA lebih tinggi bila belajar dengan strategi pembelajaran PBL.Rangkuman hasil Uji Tuckey disajikan pada tabel berikut :

Tabel 2 Rangkuman Uji Tuckey

Skor hasil belajar IPA

Multiple Comparisons

Dependent Variable: Hasil Belajar IPA Tukey HSD

\begin{tabular}{|c|c|c|c|c|}
\hline $\begin{array}{ll}\text { (I) } & \\
\mathrm{AB} & \text { (J) } \mathrm{AB}\end{array}$ & $\begin{array}{c}\text { Mea } \\
n \\
\text { Diffe }\end{array}$ & $\begin{array}{c}\text { Std. } \\
\text { Erro } \\
r\end{array}$ & Sig. & $\begin{array}{c}95 \% \\
\text { Confidence } \\
\text { Interval }\end{array}$ \\
\hline
\end{tabular}

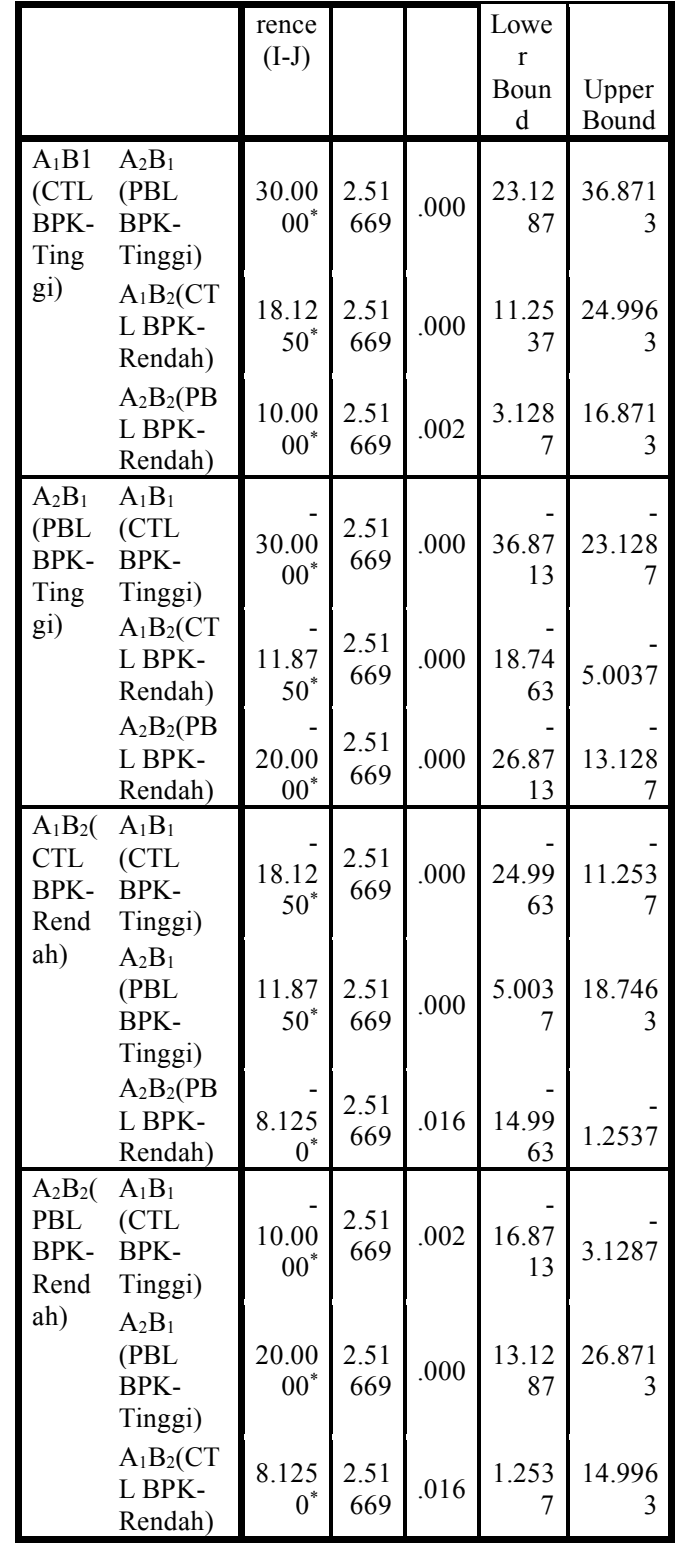

Based on observed means.

The error term is Mean

Square(Error) $=25.335$.

*. The mean difference is significant at the, 05 level.

\section{KESIMPULAN}

Berdasarkan data yang diperoleh dari hasil pengujian hipotesis dan pembahasan hasil penelitian, ditemukan beberapa hasil penelitian yang peneliti simpulkan sebagai berikut: 
a. Secara keseluruhan hasil belajar siswa dalam mata pelajaran IPA yang belajar dengan strategi pembelajaran CTL lebih tinggi daripada hasil belajar siswa dengan strategi pembelajaran PBL.

b. Hasil belajar siswa dalam mata pelajaran IPA yang memiliki keterampilan berpikir kritis tinggi, lebih baik daripada siswa yang memiiiki keterampilan berpikir kritis rendah.

c. Untuk siswa yang memiliki keterampilan berpikir kritis tinggi, hasil belajar siswa dalam mata pelajaran IPA yang belajar dengan strategi pembelajaran CTL hasilnya lebih tinggi daripada dengan PBL.

d. Untuk siswa yang memiliki keterampilan berpikir rendah, hasil belajar IPA siswa yang belajar dengan strategi pembelajaran CTL lebih rendah daripada hasil belajar IPA siswa yang belajar dengan strategi pembelajaran PBL

e. Ada pengaruh interaksi antara strategi pembelajaran dan keterampilan berpikir terhadap hasil belajar siswa dalam mata pelajaran IPA.

\section{Implikasi}

Berdasarkan kesimpulan dan implikasi penelitian di atas, maka diajukan beberapa saran bagi:

a. Kementrian Pendidikan dan Kebudayaan Republik Indonesia Program pembinaan yang telah berjalan khususnya dalam sosialisasi konsep Kurikulum 2013 sebaiknya lebih ditingkatkan. Disamping pembinaan, kegiatan pendampingan rutin untuk tiap sekolah dalam implementasi kurikulum 2013 sangat diperlukan. Pemantapan strategi pembelajaran yang sesuai untuk dilaksanakan dalam Kurikulum 2013 dapat juga didorong pengupayaannya melalui kegiatan gugus, sehingga para guru mendapat kesempatan untuk mempelajari, memahami serta terdorong untuk mengimplementasikannya.

b. Lembaga Pendidikan Tinggi

Strategi pembelajaran CTL dan PBL harus diajarkan kepada mahasiswa di lembaga pendidikan tinggi, khususnya yang menyiapkan calon guru, dan lebih khusus lagi di jurusan PGSD dan MIPA. Pembelajaran harus sampai pada tahap praktek atau microteaching sehingga dosen dapat memberikan arahan yang tepat kepada para mahasiswa. Keberagaman materi yang cocok untuk startegi pembelajaran CTL atau PBL harus dipelajari dan difahami secara benar, termasuk keunggulan dan kelemahan kedua strategi pembelajaran ini.

c. Kepala Sekolah.

Disarankan kepada kepala sekolah untuk mendorong dan membina, dengan cara memberikan kesempatan dan peluang kepada guru-guru untuk melakukan perubahan dalam usaha meningkatkan hasil belajar IPA. Hal ini dapat dilakukan antara lain dengan memberikan dukungan dan semangat kepada guru-guru untuk dapat menerapkan strategi pembelajaran CTL. 
d. Guru

Dalam rangka peningkatan hasil belajar IPA di SD, disarankan kepada guru untuk dapat menerapkan strategi pembelajaran CTL dan juga harus dapat meningkatkan keterampilan berpikir kritis siswa agar strategi pembelajaran CTL dapat dilaksanakan secara efektif. Guru juga harus melaksanakan strategi pembelajaran sesuai RPP dan dapat mendampingi serta membimbing siswa dengan sabar.

\section{REFERENSI}

Al Tabany. 2015. Mendesain Model Pembelajaran Inovatif, Progresif, dan Kontekstual. Jakarta: Prenadamedia Group.

Arends, Richard. 2012. Learning to Teach (Ninth edition). New York: McGraw Hill.

Creswell, John. 2015. Riset Pendidikan (Perencanaan, Pelaksanaan, dan Evaluasi Riset Kualitatif dan Kuantitatif). Terjemahan oleh: Helly Prajitno dan Sri Mulyantini. Yogyakarta: Pustaka Pelajar.

Daryanto. 2017. Pembelajaran Abad 21. Yogyakarta: Gava Media.

Hamalik, Oemar. 2008. Kurikulum dan Pembelajaran. Jakarta: Sinar Grafika.

Filsaime, Dennis K. 2008. Menguak Rahasia Berpikir Kritis dan Kreatif. Editor: Sunarni ME. Jakarta: Presentasi Pustaka.

Johnson, Elaine B. 2014. CTL Contextual Teaching and Learning. Terjemahan oleh: Prof. A. Chaedar Alwasilah. Bandung: Kaifa.
Mulyasa. 2009. Menjadi Guru Profesional Menciptakan Pembelajaran Yang Kreatif dan Menyenangkan. Bandung: Remaja Rosdakarya.

Oguz-Unver A, Arabacioglu S (2014). A comparison of inquiry-based learning (IBL), problem-based learning $(P B L)$ and project-based learning (PJBL) in science education. Acad. J. Educ. Res. 2(7): 120-128. (https://www.researchgate.net/publicati on/278678160_A comparison of inqu iry-based learning IBL problembased learning PBL and projectbased learning PJBL in science educ ation, diakses pada 7 Agustus 2018)

Rusman. 2010. Model-model Pembelajaran. Bandung: Rajawali Pers.

Sanjaya, Wina. 2007. Strategi Pembelajaran Berorientasi Standar Proses Pendidikan. Jakarta: Kencana Prenadamedia Group.

Stobaugh, R. 2013. Assesing Critical Thinking in Middle and High Schools: Meeting the Common Core. New York: Routledge.

Sugiyono. 2015. Metode Penelitian Pendidikan Pendekatan Kuantitatif, Kualitatif, dan $R \& D$. Bandung: Alfabeta

Susanto, Ahmad. 2014. Teori Belajar dan Pembelajaran di Sekolah Dasar. Jakarta: Kencana. 